The University of Maine

DigitalCommons@UMaine

Earth Science Faculty Scholarship

Earth Sciences

9-1999

\title{
Maximum Temperature Trends in the Himalaya and Its Vicinity: An Analysis Based on Temperature Records from Nepal for the Period 1971-94
}

Arun B. Shrestha

Camerson P.Wake

Paul Andrew Mayewski

University of Maine, paul.mayewski@maine.edu

Jack E. Dibb

Follow this and additional works at: https://digitalcommons.library.umaine.edu/ers_facpub

Part of the Climate Commons, Glaciology Commons, Hydrology Commons, and the Meteorology Commons

\section{Repository Citation}

Shrestha, Arun B.; Wake, Camerson P.; Mayewski, Paul Andrew; and Dibb, Jack E., "Maximum Temperature Trends in the Himalaya and Its Vicinity: An Analysis Based on Temperature Records from Nepal for the Period 1971-94" (1999). Earth Science Faculty Scholarship. 274.

https://digitalcommons.library.umaine.edu/ers_facpub/274

This Article is brought to you for free and open access by DigitalCommons@UMaine. It has been accepted for inclusion in Earth Science Faculty Scholarship by an authorized administrator of DigitalCommons@UMaine. For more information, please contact

um.library.technical.services@maine.edu. 


\title{
Maximum Temperature Trends in the Himalaya and Its Vicinity: An Analysis Based on Temperature Records from Nepal for the Period 1971-94
}

\author{
Arun B. Shrestha, ${ }^{*}$ Cameron P. Wake, ${ }^{+}$Paul A. Mayewski, ${ }^{+}$and Jack E. Dibb ${ }^{+}$ \\ Climate Change Research Center, Institute for the Study of the Earth, Oceans, and Space, University of New Hampshire, \\ Durham, New Hampshire
}

(Manuscript received 3 August 1997, in final form 2 November 1998)

\begin{abstract}
Analyses of maximum temperature data from 49 stations in Nepal for the period 1971-94 reveal warming trends after 1977 ranging from $0.06^{\circ}$ to $0.12^{\circ} \mathrm{C} \mathrm{yr}^{-1}$ in most of the Middle Mountain and Himalayan regions, while the Siwalik and Terai (southern plains) regions show warming trends less than $0.03^{\circ} \mathrm{C} \mathrm{yr}^{-1}$. The subset of records (14 stations) extending back to the early 1960s suggests that the recent warming trends were preceded by similar widespread cooling trends. Distributions of seasonal and annual temperature trends show high rates of warming in the high-elevation regions of the country (Middle Mountains and Himalaya), while low warming or even cooling trends were found in the southern regions. This is attributed to the sensitivity of mountainous regions to climate changes. The seasonal temperature trends and spatial distribution of temperature trends also highlight the influence of monsoon circulation.

The Kathmandu record, the longest in Nepal (1921-94), shows features similar to temperature trends in the Northern Hemisphere, suggesting links between regional trends and global scale phenomena. However, the magnitudes of trends are much enhanced in the Kathmandu as well as in the all-Nepal records. The authors' analyses suggest that contributions of urbanization and local land use/cover changes to the all-Nepal record are minimal and that the all-Nepal record provides an accurate record of temperature variations across the entire region.
\end{abstract}

\section{Introduction}

Studies on long-term variations in surface air temperature for the entire globe (Jones et al. 1986c; Hansen and Lebedeff 1987, 1988) as well as for the hemispheres (Angell and Korshover 1978; Jones et al. 1986a,b) have shown a rising trend during the last few decades. Similar results have been found for low-latitude regions in the Northern Hemisphere.

Mountainous environments are considered sensitive indicators of climate change (Barry 1990; Stone 1992; Beniston 1994). Several studies in the Himalayas have found that glaciers in the region have retreated considerably in the last two decades (Higuchi et al. 1980; Miller 1989; Miller and Marston 1989; Yamada et al. 1992; Kadota et al. 1993). Recent studies have identified the formation and growth of several glacial lakes, pos-

\footnotetext{
* Additional affiliation: Department of Hydrology and Meteorology, HMG-Nepal, Kathmandu, Nepal.

+ Additional affiliation: Department of Earth Sciences, University of New Hampshire, Durham, New Hampshire.
}

Corresponding author address: Dr. Arun B. Shrestha, Department of Hydrology and Meteorology, P.O. Box 406, Kathmandu, Nepal. E-mail: abs@wlink.com.np sibly due to fast retreat of glaciers, which could lead to catastrophic outburst floods (Vuichard and Zimmermann 1987). It is possible that global warming is responsible for the recent glacial retreat in the Himalayas, although precipitation changes may also be important. However, Seko and Takahashi (1991) have suggested that over the last decade, glacier fluctuation in the Khumbu Himal followed the fluctuations in air temperature more than those in precipitation. Mayewski and Jeschke (1979) have suggested that Himalayan glaciers have been retreating since 1850 A.D. It is possible that the cooling in 1940 observed in the global record caused readvancing of these glaciers, and the warming after the mid-1970s resulted in accelerated shrinking in the past two decades.

The Himalaya and Tibetan Plateau play an important role in regional climate, most particularly with respect to monsoon circulation. Links between the monsoon and other global-scale phenomena extend the implications of climatic variations in the Himalaya and in the Tibetan Plateau beyond the regional scale (Dey and Bhanu Kumar 1982, 1983; Barnett et al. 1988). Climatic changes in the Himalayan region could be a reflection of largescale climate changes, or they could even be driving them.

It is therefore important to understand the climatic 
trends in the Himalaya and their relationship with global trends. Unfortunately, the instrumental meteorological records from high elevations [i.e., greater than $4000 \mathrm{~m}$ above mean sea level (MSL)] of the Himalaya are relatively short (i.e., 5-7 yr; Grabs and Pokhrel 1992) and therefore provide only limited information on changes in high-elevation climate. Meteorological data from the Tibetan Plateau are also rare. Studies on climatic trends, therefore, have to rely on records from stations south of the Himalaya or from outside the Tibetan Plateau. A study of the long-term trend in surface air temperatures in India by Hingane et al. (1985) indicated an increase in mean annual temperature of $0.4^{\circ} \mathrm{C}$ over the past century. A study of changes in air temperature of QinghaiXizang (Tibetan) Plateau showed a decreasing trend from 1950 to 1970 and an increase after $1970(\mathrm{Li}$ and Tang 1986).

The present study is the first to be based on surface temperature data from a network of stations in Nepal. Individual records dating back to the early 1960s were investigated to reveal temperature trends in various geographical settings and demographic situations. Based on this, a period representative of present temperature trends was selected. For the period selected, annual and seasonal patterns of maximum temperature trends in $\mathrm{Ne}$ pal were investigated. Further, temperature trends from Kathmandu Valley, which has the longest record in $\mathrm{Ne}-$ pal (1921-94), were compared to large-scale (global) temperature trends.

\section{Data and methods}

Physiographically, Nepal can be divided into six regions: Terai, Siwalik, Middle Mountains, High Mountains, High Himalaya, and Tibetan Plateau (WECS 1986). The elevation ranges from $65 \mathrm{~m}$ MSL in the Terai to over 8000 m MSL in the High Himalaya. About 90\% of the country is characterized by mountainous terrain.

With the purpose of representing all parts of the country, 49 temperature stations were selected (Table 1). Among them, records from 33 stations begin in 1971, while records from 14 stations begin in the early to mid1960s. The record from the Kathmandu Indian Embassy (Kathmandu IE) is the longest, dating back to 1921.

Data for all the stations were collected and published by the Department of Hydrology and Meteorology (DHM), His Majesty's Government (HMG) of Nepal. Data from 1971 to 1994 for most of the stations are published, while data after 1994 are still in the preliminary stage of publication and not in accessible formats (DHM 1998). Temperature data are available as monthly means of daily maxima and minima. A preliminary analysis showed high year-to-year fluctuation and lack of significant trend in minimum temperature in most of the station records in Nepal. Furthermore, minimum temperatures have been found to be more affected by urbanization compared to maximum temperature (Mitchell 1961). Therefore we used maximum temperatures for our analysis, which are hereafter referred to simply as temperature.

We used the temperature anomaly for $24^{\circ}-40^{\circ} \mathrm{N}$ as an indicator of large-scale Northern Hemisphere midlatitude temperature trends. This dataset was obtained from the Goddard Institute for Space Studies online data products (Hansen et al. 1996) and is hereafter referred to as the $24^{\circ}-40^{\circ} \mathrm{N}$ temperature anomaly.

All the Nepal stations' data were carefully analyzed for homogeneity and for missing data. We only selected stations where instrument locations were not significantly changed within the period of record. Further, the relative homogeneity test was conducted by graphical study of ratios of temperature records from neighboring stations (WMO 1966). Any inhomogeneity in the record is depicted by a significant departure of the ratio from the mean. About 15 stations were discarded as a result of this test. The stations selected for this study did not show such inhomogeneity and had few missing data. Missing data were filled by temporal and spatial interpolation whenever possible.

Annual and seasonal means were calculated for each year for all stations. The four seasons are divided as winter (December of previous year, January, and February), premonsoon (March-May), monsoon (JuneSeptember), and postmonsoon (October and November). Annual mean is the average of January-December monthly means.

Seasonal and annual temperature trends were computed for all stations using linear regression. Spatial distributions of temperature trends were computed by interpolating the station trends to a rectangular block of $26.25^{\circ}-30.25^{\circ} \mathrm{N}$ and $80.25^{\circ}-88.25^{\circ} \mathrm{E}$ with the grid size of $0.25^{\circ} \times 0.25^{\circ}$. The error associated with the use of a rectangular block instead of a spherical one will be minimal due to the small area considered in the study. The grid size was selected in such a way that close stations were individually represented. For the selection of the grid size, interpolations were performed by gradually reducing the grid size until further reduction did not provide a significant change in the results. An analysis and visualization program (Spyglass 3.01) was used for interpolation by Kriging. Kriging is superior to any other interpolation method because in this method all known and missing data values are assigned a variance and a variance matrix is generated. Kriging is considered to be the best interpolation algorithm when the known values are fewer than 100 and missing values are relatively more (Fortner 1992). To test this algorithm, mean annual temperature maps of Nepal were prepared using several interpolation techniques with the same number of stations. Kriging provided the best result, as the map prepared by this technique clearly showed elevational and latitudinal gradient in temperature, much similar to maps prepared by the DHM, HMG using much more station data.

Based on the annual and seasonal distributions of temperature trends, mean trends for different physio- 
TABLE 1. Descriptions of stations included in this study.

\begin{tabular}{|c|c|c|c|c|c|}
\hline Station no. ${ }^{\mathrm{a}}$ & Station name & $\begin{array}{l}\text { Elevation } \\
\text { (m) }\end{array}$ & $\begin{array}{l}\text { Latitude } \\
\left({ }^{\circ} \mathrm{N}\right)\end{array}$ & $\begin{array}{c}\text { Longitude } \\
\left({ }^{\circ} \mathrm{E}\right)\end{array}$ & $\begin{array}{l}\text { Physiographic } \\
\text { regions }\end{array}$ \\
\hline 0203 & Silgadi Doti & 1360 & 29.27 & 80.98 & $\mathrm{MM}$ \\
\hline 0207 & Tikapur & 140 & 28.50 & 80.95 & TAR \\
\hline 0209 & Dhangadi & 1360 & 28.68 & 80.60 & TAR \\
\hline 0215 & Godavari (W) & 288 & 28.87 & 80.63 & TAR \\
\hline 0303 & Jumla & 2300 & 29.28 & 82.17 & $\mathrm{H}$ \\
\hline 0401 & Pusma Camp & 950 & 28.88 & 81.25 & MM \\
\hline 0402 & Dailekh $^{c}$ & 1402 & 28.85 & 81.72 & MM \\
\hline 0405 & Chisapani $^{\mathrm{c}}$ & 225 & 28.65 & 81.27 & SW \\
\hline 0406 & Surkhet & 720 & 28.60 & 81.62 & SW \\
\hline 0409 & Khajura & 190 & 28.10 & 81.57 & TAR \\
\hline 0416 & Nepalgunj & 144 & 28.07 & 81.62 & TAR \\
\hline 0508 & Talsipur & 725 & 28.13 & 82.30 & SW \\
\hline 0604 & Thakmarpha & 2566 & 28.75 & 83.70 & $\mathrm{TH}$ \\
\hline 0612 & Mustang & 3705 & 29.18 & 83.97 & $\mathrm{TH}$ \\
\hline 0703 & Butwal & 205 & 27.70 & 83.47 & SW \\
\hline 0705 & Bhairahawa & 110 & 27.52 & 83.43 & TAR \\
\hline 0706 & Dumkauli & 154 & 27.68 & 84.22 & SW \\
\hline 0707 & Bhairahawa AG & 120 & 27.53 & 83.47 & TAR \\
\hline 0802 & Khudi Bazarc & 823 & 28.28 & 84.37 & SW \\
\hline 0804 & Pokhara Airport ${ }^{\mathrm{c}}$ & 827 & 28.22 & 84.00 & MM \\
\hline 0809 & Gorkha $^{\mathrm{c}}$ & 1097 & 28.00 & 84.62 & MM \\
\hline 0811 & Malepatan Pokhara & 856 & 28.22 & 83.95 & MM \\
\hline 0814 & Lumle & 1642 & 28.30 & 83.80 & MM \\
\hline 0815 & Khairini Tar & 190 & 28.03 & 84.10 & MM \\
\hline 0902 & Rampurc & 256 & 27.62 & 84.42 & SW \\
\hline 0905 & Daman & 2314 & 27.60 & 85.08 & MM \\
\hline 0906 & Hetaunda NFI & 466 & 27.42 & 85.05 & SW \\
\hline 0909 & Simara Apt & 130 & 27.17 & 84.98 & TAR \\
\hline 0911 & Parwanipur & 115 & 27.07 & 84.97 & TAR \\
\hline 1007 & Kakani & 2064 & 27.80 & 85.25 & MM \\
\hline 1022 & Godavari & 1400 & 27.58 & 85.40 & MM \\
\hline 1029 & Khumaltar & 1350 & 27.67 & 85.33 & MM \\
\hline 1030 & Kathmandu airport ${ }^{\mathrm{c}}$ & 1336 & 27.70 & 85.37 & MM \\
\hline 1039 & Panipokhari & 1335 & 27.73 & 85.35 & MM \\
\hline 1043 & Nagarkot & 2150 & 27.72 & 85.52 & MM \\
\hline 1103 & Jiri $^{\mathrm{c}}$ & 2003 & 27.63 & 86.23 & $\mathrm{H}$ \\
\hline 1111 & Janakpur airport & 90 & 26.72 & 85.97 & TAR \\
\hline 1206 & Okhaldungac $^{c}$ & 1720 & 27.32 & 86.50 & $\mathrm{H}$ \\
\hline 1209 & Bhojpur IMD ${ }^{c}$ & 1595 & 27.18 & 87.05 & MM \\
\hline 1220 & Chialsa $^{\mathrm{c}}$ & 2770 & 27.52 & 86.62 & $\mathrm{H}$ \\
\hline 1303 & Chainpur ${ }^{\mathrm{c}}$ & 1329 & 27.28 & 87.33 & $\mathrm{H}$ \\
\hline 1304 & Pakhribas & 1677 & 27.05 & 87.28 & MM \\
\hline 1307 & Dhankuta & 1160 & 26.98 & 87.35 & MM \\
\hline 1319 & Biratnagar airport & 72 & 26.48 & 87.27 & TAR \\
\hline 1320 & Tarahara & 200 & 26.70 & 87.27 & SW \\
\hline 1323 & Dharan BC & 400 & 26.78 & 87.28 & SW \\
\hline 1405 & Taplejung & 1732 & 27.35 & 87.67 & $\mathrm{H}$ \\
\hline 1407 & Ilam Tea Estate & 1300 & 26.92 & 87.90 & SW \\
\hline 1416 & Kanyam Tea Estate & 1658 & 26.87 & 88.07 & SW \\
\hline
\end{tabular}

a Station numbers according to Department of Hydrology and Meteorology station index numbers. Numbers increase from west to east, and north to south.

b TAR stands for Terai, SW stands for Siwalik, MM represents Middle Mountain, H stands for Himalayan, and TH stands for TransHimalayan regions.

c Stations with records starting from or before mid-1960s.

graphical regions and for the whole country were calculated. Due to the low number of high-elevation stations, we combined stations in the High Mountain and High Himalaya regions. The combined region is referred to as the Himalayan region (Fig. 1). Annual mean station temperatures were spatially interpolated for each individual year from 1971 to 1994, and regional and allNepal mean temperatures were derived for that period.
The Kathmandu IE record extends from 1921 to 1976. We used multiple linear regression between this station and four others in the Kathmandu Valley during the period of overlap (1971-76) to create a single Kathmandu record through 1994. The extension of the Kathmandu IE record by this method allowed us to directly compare the extended record with records representing larger-scale trends. Nevertheless, it has to be noted here 


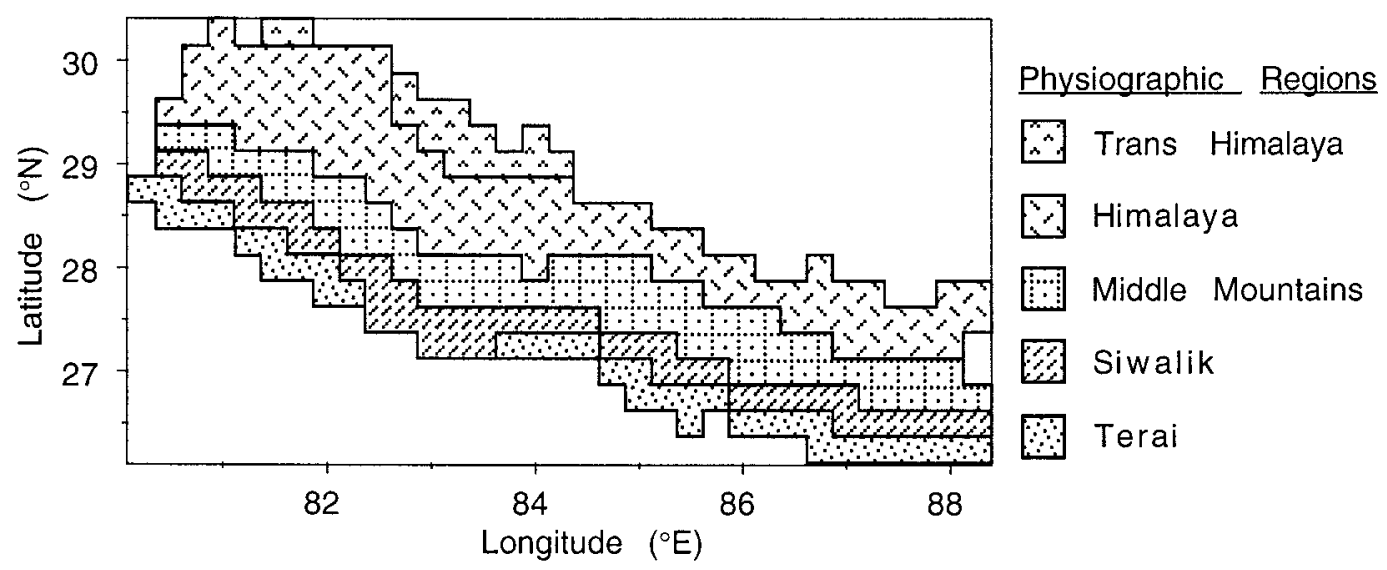

FIG. 1. Delineation of physiographic regions of Nepal. The grid size is $0.25^{\circ} \times 0.25^{\circ}$.

that due to a short overlap period $(6 \mathrm{yr})$ it was not possible to test the values with actual observations.

\section{Results}

\section{a. Analysis of individual station records}

Records from all 14 stations that begin in the mid1960s were individually-analyzed. Mean annual maximum temperature plots of almost all of these records show one basic characteristic: decreasing or constant trends in the earlier part of the records and increasing trends in the latter part of the records (Fig. 2a). The turning points (identified by arrowheads in Fig. 2a) were determined visually and verified by fitting a fifth-order polynomial function. Interestingly, these points in most of these records occur around the mid-1970s. Exceptions are Chisapani, which shows a decreasing trend throughout the record period; Chialsa, which shows an increasing trend throughout the record period; and Chainpur, which does not show any distinct trend. In contrast, minimum temperatures for these station show high interannual variability, while they do not display any significant trends (Fig. 2b)

\section{b. Regional and all-Nepal annual temperature trends}

The spatial distribution of annual mean temperatures was calculated using Kriging for the period 1971-94. Based on this distribution, temperature trends were derived for five different physiographical regions as well as for the whole country. Temperature trends in the five regions and the country were constant or decreasing before 1978, whereas after 1978 they were increasing (Fig. 3). This result is consistent with the result obtained from analyses of individual stations. Therefore the period 1977-94 was selected for further analysis.

Regional and all-Nepal temperature trends change from season to season. The greatest warming trend is observed in the postmonsoon season (Table 2). According to seasonal as well as annual warming trends, the five regions may be divided into two groups. TransHimalayan, Himalayan, and Middle Mountain regions fall in the first group with high warming rates, while Siwalik and Terai regions fall in the second group as they show low warming rates. However, for the postmonsoon season even the Siwalik and the Terai regions show high warming rates.

While simple linear regression is an easy technique for qualitative assessments of trends in climatological parameters, this technique has some limitations. Presence of outliers and nonnormality in a short record can limit the usefulness of linear regression. To check this possibility we carried out nonparametric tests (MannKendall test and Spearman test) for trends in the temperature records (WMO 1966). These tests reduce the temperature data to ranks rather than magnitudes, thereby eliminating the influence of outliers. Results of these tests support the results of the simple linear regression (Table 3), although they do not provide alternative measures of slopes. While other more sophisticated techniques are available, we chose to implement simple regression analysis and Mann-Kendall and Spearman tests because of ease of interpretation and availability. Results of the simple linear regression are used for quantitative comparisons.

\section{c. Seasonal and annual temperature trends}

The spatial distributions of mean annual temperature trends over the period 1977-94 are presented in Fig. 4a. The mean annual maximum temperature trend distributions show warming in most parts of the country. High mean annual temperature increases $\left(>0.06^{\circ} \mathrm{C} \mathrm{yr}^{-1}\right)$ occur in most of the northern belt (the Trans-Himalayan and Himalayan regions and central and western parts of the Middle Mountains). Within the Middle Mountain region there are two pockets of anomalously high warming rates $\left(\geq 0.12^{\circ} \mathrm{C} \mathrm{yr}^{-1}\right)$ : the western Middle Mountain region and the Kathmandu Valley. Most of the Siwalik and the Terai regions show considerably low increasing 

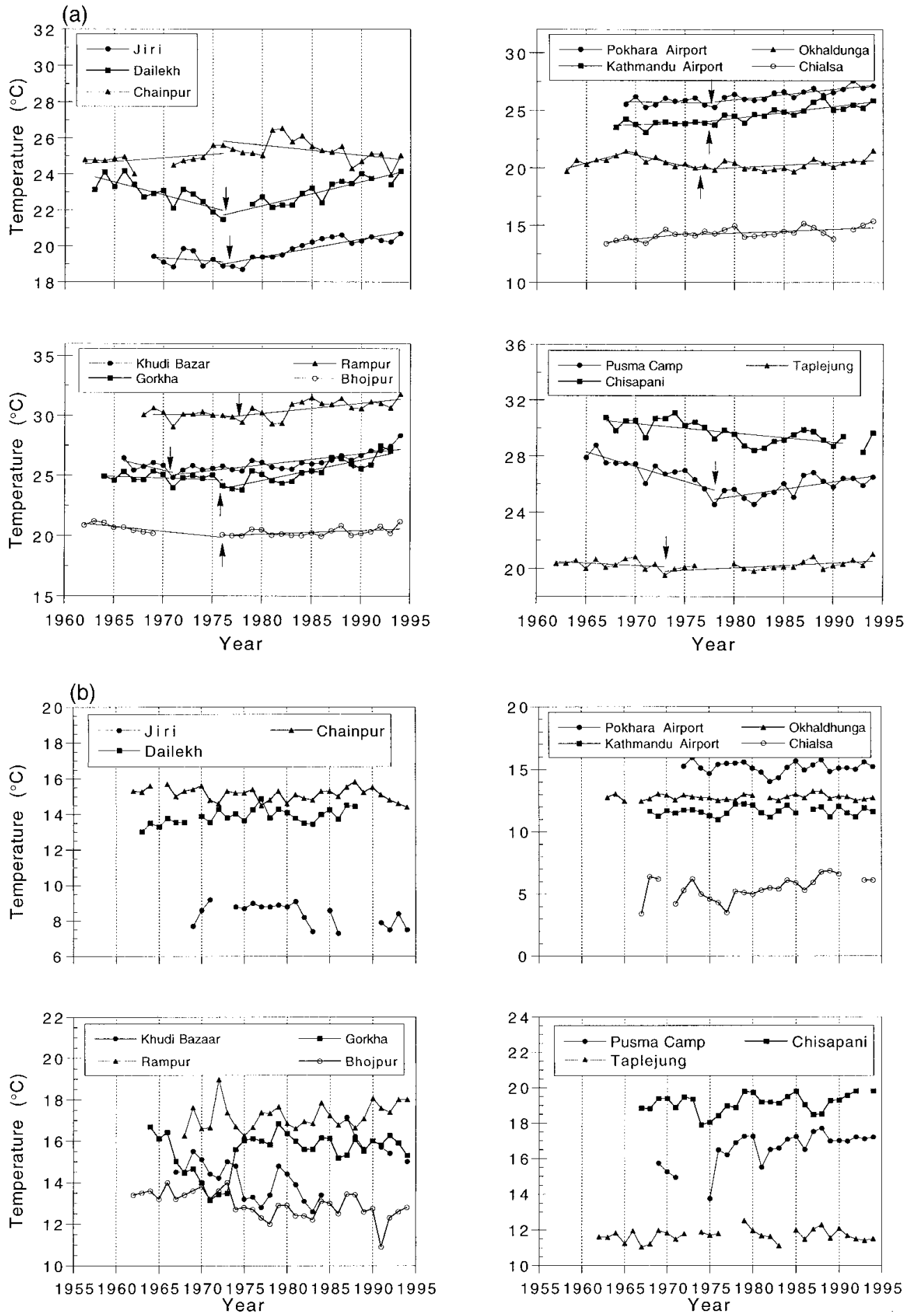

FIG. 2. Temperature trends in 14 stations with records extending back to early to mid-1960s: (a) maximum and (b) minimum temperatures. Arrows indicate possible turning points in those records.

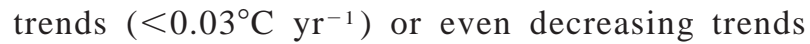

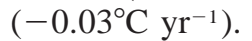

Winter, premonsoon, and monsoon temperature trend distributions closely resemble the yearly temperature distribution, with the winter season showing the greatest and the premonsoon season showing the lowest rate of increase (Figs. 4b,c). As in the case of annual temperature trend distributions, most of the northern, central, and midwestern parts of the country show high rates of increase in temperature. The contrast in temperature 

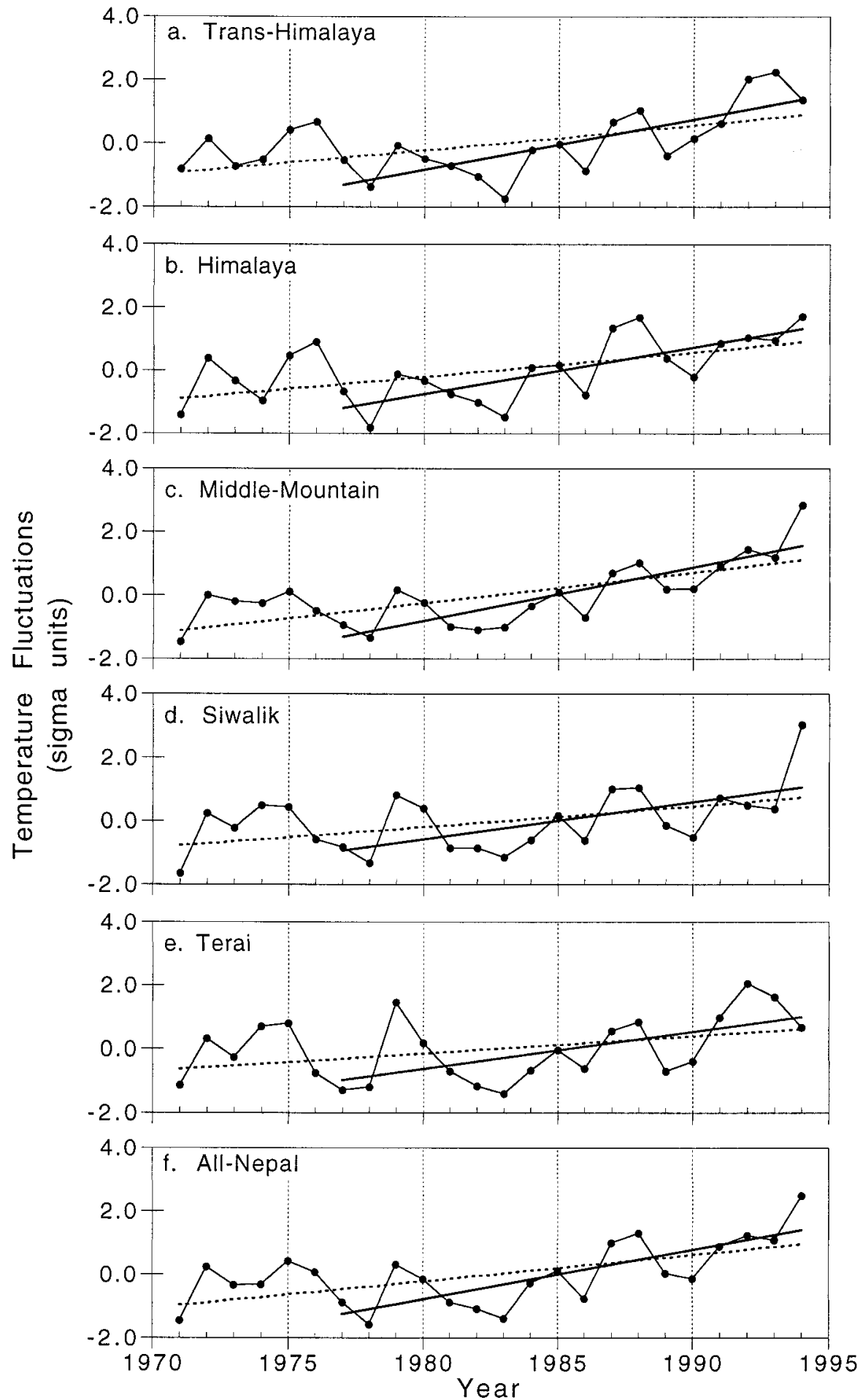

FIG. 3. Time series of mean maximum temperatures for (a) Trans-Himalaya, (b) Himalaya, (c) Middle Mountain, (d) Siwalik, (e) Terai regions, and (f) all-Nepal. 
TABLE 2. Regional mean temperature trends for the period $1977-94\left({ }^{\circ} \mathrm{C} \mathrm{y}^{-1}\right)$

\begin{tabular}{|c|c|c|c|c|c|}
\hline \multirow[b]{2}{*}{ Regions } & \multicolumn{4}{|c|}{ Seasonal } & \multirow[b]{2}{*}{$\begin{array}{l}\text { Annual } \\
\text { Jan-Dec }\end{array}$} \\
\hline & $\begin{array}{c}\text { Winter } \\
\text { Dec-Feb }\end{array}$ & $\begin{array}{c}\text { Premonsoon } \\
\text { Mar-May }\end{array}$ & $\begin{array}{l}\text { Monsoon } \\
\text { Jun-Sep }\end{array}$ & $\begin{array}{c}\text { Postmonsoon } \\
\text { Oct-Nov }\end{array}$ & \\
\hline Trans-Himalaya & $0.124^{\mathrm{a}}$ & 0.005 & $0.109^{\mathrm{b}}$ & $0.099^{c}$ & $0.0900^{\mathrm{b}}$ \\
\hline Himalaya & $0.090^{\mathrm{b}}$ & 0.050 & $0.062^{\mathrm{b}}$ & $0.075^{\mathrm{a}}$ & $0.057^{\mathrm{b}}$ \\
\hline Middle Mountains & $0.059^{\mathrm{c}}$ & 0.050 & $0.055^{\mathrm{b}}$ & $0.094^{\mathrm{b}}$ & $0.075^{\mathrm{b}}$ \\
\hline Siwalik & 0.015 & 0.010 & 0.021 & $0.077^{\mathrm{a}}$ & $0.041^{\mathrm{a}}$ \\
\hline Terai & 0.006 & -0.004 & 0.014 & $0.069^{a}$ & $0.041^{\mathrm{a}}$ \\
\hline All-Nepal & $0.061^{\mathrm{a}}$ & 0.032 & $0.051^{\mathrm{a}}$ & $0.081^{\mathrm{b}}$ & $0.059^{\mathrm{b}}$ \\
\hline
\end{tabular}

${ }^{\mathrm{a}} \mathrm{p} \geq 0.01$.

${ }^{b} \mathrm{p} \geq 0.001$.

${ }^{\mathrm{c}} \mathrm{P} \geq 0.05$.

trends between the northern and southern regions is much greater for the monsoon season (Fig. 4d). The postmonsoon temperature trend distribution is strikingly different from all other distribution patterns (Fig. 4e). Almost the entire country shows an increasing trend during this season.

\section{d. Comparison with Northern Hemisphere temperature anomaly}

To study relationships between temperature trends in Nepal and global-scale trends, we compared the Kathmandu annual temperature with the $24^{\circ}-40^{\circ} \mathrm{N}$ annual temperature anomaly after applying a 10-yr running mean to both records (Fig. 5). There are some striking similarities between these records. The $24^{\circ}-40^{\circ} \mathrm{N}$ temperature shows a rising trend before 1940, a decreasing trend from 1938 to 1972 , and an increasing trend again after 1972. There is a general trend of cooling from 1935 to 1974 in the Kathmandu record. This period, however, was interrupted by two episodes of warming (1948-54 and 1964-69) and subsequent cooling (195464 and 1969-74). The last warming trend in the Kathmandu record is the longest monotonic trend in the entire record. The range of cooling and warming in these records are of different magnitudes. The cooling of 1940-70 lowered the $24^{\circ}-40^{\circ} \mathrm{N}$ temperature by about $0.23^{\circ} \mathrm{C}$, while in the Kathmandu record, the drop in temperature from $1934-75$ is about $0.6^{\circ} \mathrm{C}$. Similarly, the warming after 1970 has raised the $24^{\circ}-40^{\circ} \mathrm{N}$ temperature by about $0.5^{\circ} \mathrm{C}$, whereas the Kathmandu temperature has risen by $1{ }^{\circ} \mathrm{C}$ since 1975 .

For comparison, the all-Nepal annual temperature record and annual temperature records of four Kathmandu Valley stations are also presented in Fig. 5. The all-Nepal temperature shows a rise in temperature of about $0.9^{\circ} \mathrm{C}$ since 1977 .

\section{Discussion}

The presence of general cooling or constant trends before 1970 and warming after the mid-1970s in most of the Nepal station records extending back to the early 1960s (Fig. 2a), and similar warming in regional as well as all-Nepal temperature trends (Fig. 3), demonstrates the spatial coherence of these records despite tremendous contrast in the physiographic and demographic characteristics among the stations. This in turn suggests that the Nepal meteorological station data presented here reflect regional climatic trends that predominate over the whole country. The relatively high rate of warming in the all-Nepal record after the mid-1970s is due predominantly to the high rates of warming in the highelevation areas of the Himalaya and Middle Mountain regions. The mountainous regions of Nepal therefore appear to be amplifying the regional warming trend, which supports the concept that alpine regions provide a sensitive indicator of climate change.

The recent reduction of snow and glacier cover in the Himalaya may also be contributing to the higher rates of warming observed in the higher-elevation regions of Nepal (e.g., Yamada et al. 1992; Kadota and Ageta 1992; Fujita et al. 1997). A reduction in snow and glacier cover in the high elevation will change the surface albedo of the region, which in turn will increase the surface air temperature, thereby acting as a positive feedback mechanism (e.g., Meehl 1994). The importance of snow and glacier cover variations is manifested by the effect of the Eurasian snow cover variations on the regional climate, mainly the summer monsoon, as suggested by several empirical as well as model studies (Dey and Bhanu Kumar 1982, 1983; Khandekar 1991).

Seasonal temperature trend distributions appear to be influenced by summertime monsoon circulation. The increased warming rate in the highlands in the north and low warming or cooling in the plains in the south during the monsoon season (Fig. 4d) are possibly due to the advection of moisture and associated increased cloudiness in the south, while comparatively dry and fair weather dominates in the north. This may also account for the lower rates of warming in the Middle Mountain and Siwalik regions. Siwalik (700-1500 m MSL) is where the monsoon circulation encounters the first orographic barrier, and the region receives a large amount of monsoon precipitation. The Middle Mountain contains the Mahabharat range (1500-2700 m MSL), the 
TABLE 3. Nonparametric tests for trends for the period 1971-94 for annual mean maximum temperatures and for the period 1977-94 for annual and seasonal mean maximum temperatures.

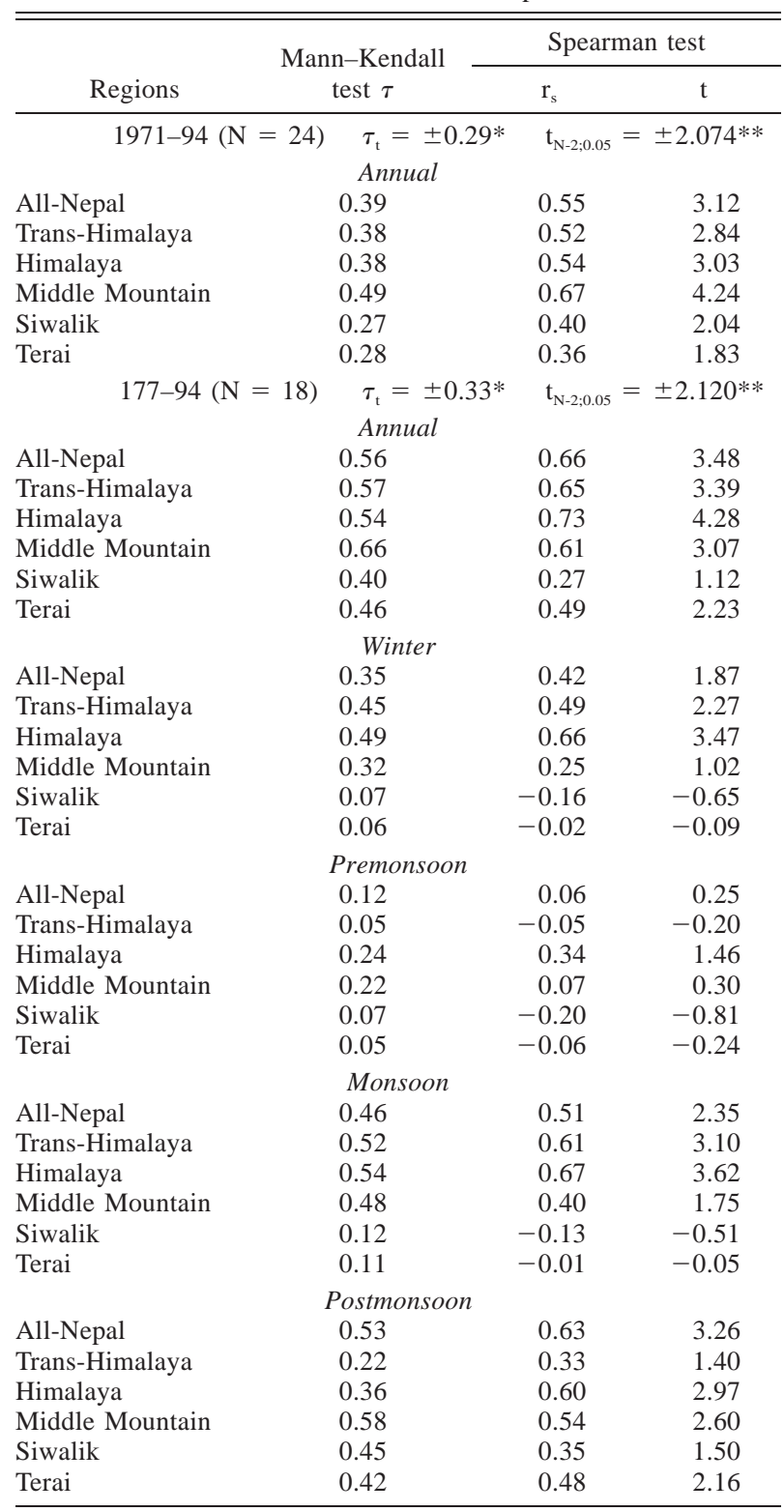

$* \tau$ values beyond this range indicate $\mathrm{p} \geq 0.05$.

$* * \mathrm{t}$ values beyond this range indicate $\mathrm{p} \geq 0.05$.

second, but a higher, barrier to monsoon circulation, which results in several pockets of very high precipitation (Shankar and Shrestha 1985). Similarly, the increased warming rate during the postmonsoon season is likely linked to the retreat of monsoons. The extent of cloud cover has been found to minimize the temperature difference between urban sites and rural sites by reducing the magnitude of urban heat islands (Sundborg 1951). The actual mechanism that connects monsoon circulation and the observed differences in temperature trends is difficult to explain. It is possible that a mech- anism similar to that operating in the case of urban heat islands is also responsible for the reduction of largerscale warming. Another possibility is a feedback mechanism in the form of a strengthened monsoon due to warming in the Himalayas (and possibly in the Tibetan Plateau). A stronger monsoon is associated with increased cloudiness, hence reducing the warming rate. The lack of cloud cover data precludes the possibility of investigating cloud cover variations in the region. A separate study on precipitation fluctuations in Nepal is in progress. Results of this study may help test the hypothesis presented here on the relationship between temperature trends and monsoons. Preliminary results of the study indicate some increases in monsoon precipitation in the country, which is in agreement with model prediction regarding increase in monsoon precipitation with global warming (e.g., Follard et al. 1990).

The temperature trends found in the Kathmandu record are similar to those in the Tibetan Plateau, which showed decrease in temperature from the 1950s to the 1970s and warming thereafter (Li and Tang 1986). Warming after 1965 was also observed in temperature records from the Ganges basin in India (Kothyari and Shing 1996). The temperature trend of India as a whole, however, is different as it shows low and constant warming over the whole century, lacking the cooling around the 1940s and the distinct warming after the 1970s (Hingane et al. 1985). It is likely that the southern part of the Indian subcontinent is behaving climatologically differently than the Himalayan region.

Nearly synchronous cooling and warming trends in the Kathmandu and the $24^{\circ}-40^{\circ} \mathrm{N}$ temperature anomaly records indicate links between temperature trends in $\mathrm{Ne}$ pal and large-scale trends (Fig. 5). Despite the visual resemblance between the Kathmandu record and the $24^{\circ}-40^{\circ} \mathrm{N}$ temperature records, there is a large difference in the magnitude of warming. The Kathmandu Valley has experienced tremendous urbanization associated with remarkable population growth in the last two decades (Sharma 1986; CBS 1995; EPC 1993). Nevertheless, it is unlikely that the warming trend in the Kathmandu record is due only to the urbanization, mainly because even the cooling rate between 1934 and 1975 in the Kathmandu record greatly exceeded the global cooling between 1940 and 1970, and this cannot be attributed to urban effects. Moreover, the urban effect of Kathmandu City should have been negligible in the 1940s. It is possible that the high warming rate observed in the record from Kathmandu is due to its physiographical characteristics, which may make the valley more sensitive to climatic change. The Kathmandu record may in general be reflecting the large-scale Northern Hemisphere trend with some amplification, while the last two decades may have had the additional influence of urbanization.

Although the warming trend after the mid-1970s in the all-Nepal record is slightly lower than that in the Kathmandu record, it is still greater than the global 

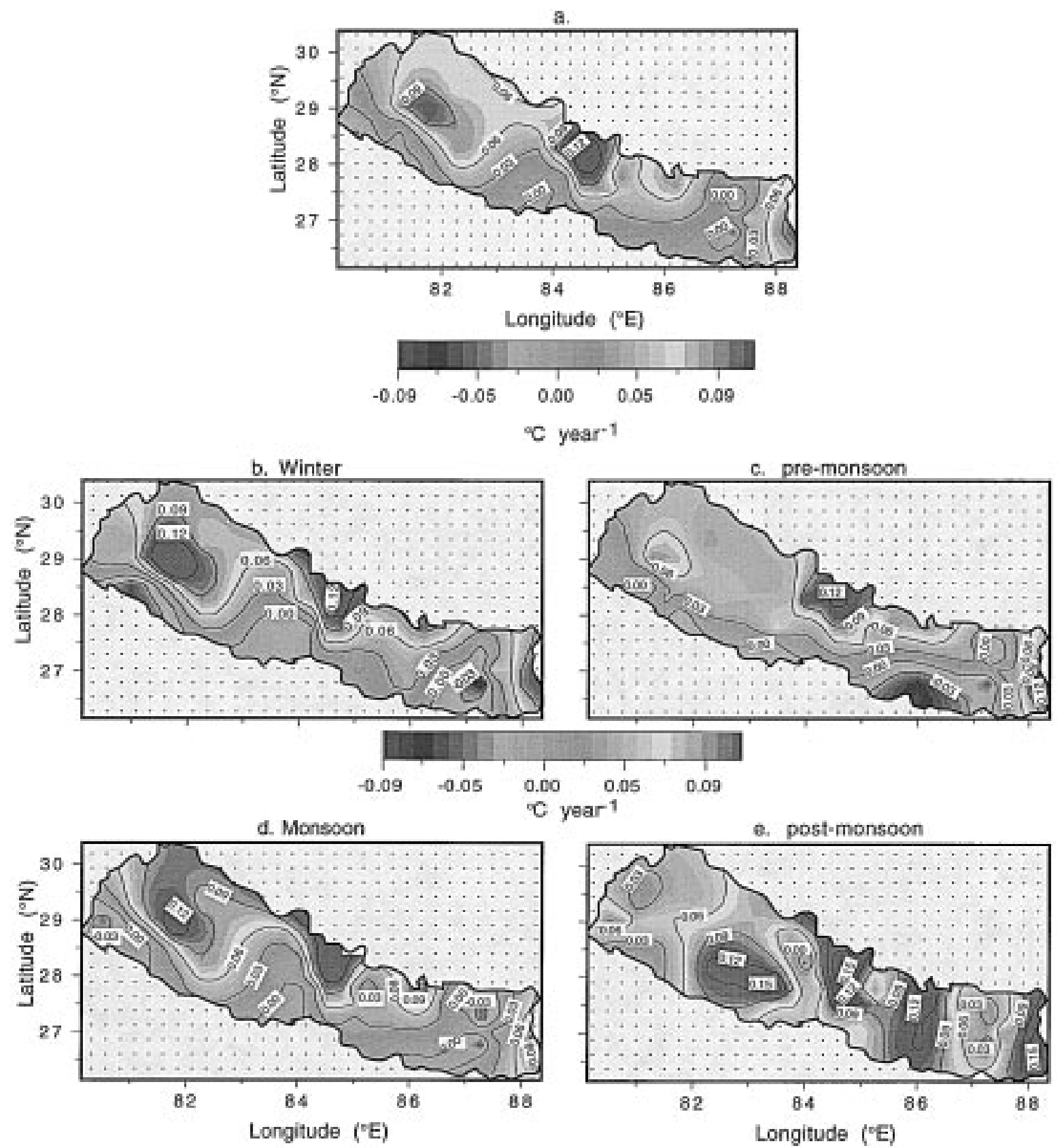

FIG. 4. Spatial distributions of mean temperature trends for the period 1977-94 for (a) annual, (b) winter, (c) premonsoon, (d) monsoon, and (e) postmonsoon seasons.

trend. The all-Nepal temperature trend, which is a spatial average of all station records, also includes station records that may have been influenced by urbanization. Nevertheless, the net effect of such stations is minimal because of their localized nature. A similar conclusion was also drawn by Hansen et al. (1996) regarding the influence of urban warming on the global temperature analysis. Furthermore, high warming trends are observed in the Himalayan and Trans-Himalayan region, which lack urban centers. It is therefore concluded that the all-Nepal trend is not biased by urban effects. The presence of trends in several stations with records dating back to the early 1960s, similar to that in the Kathmandu record, supports that warming trends observed in the records from Nepal are not local phenomena but are occurring on a countrywide or regional scale.

Also associated with population growth are radical changes in land use and land cover over the country 


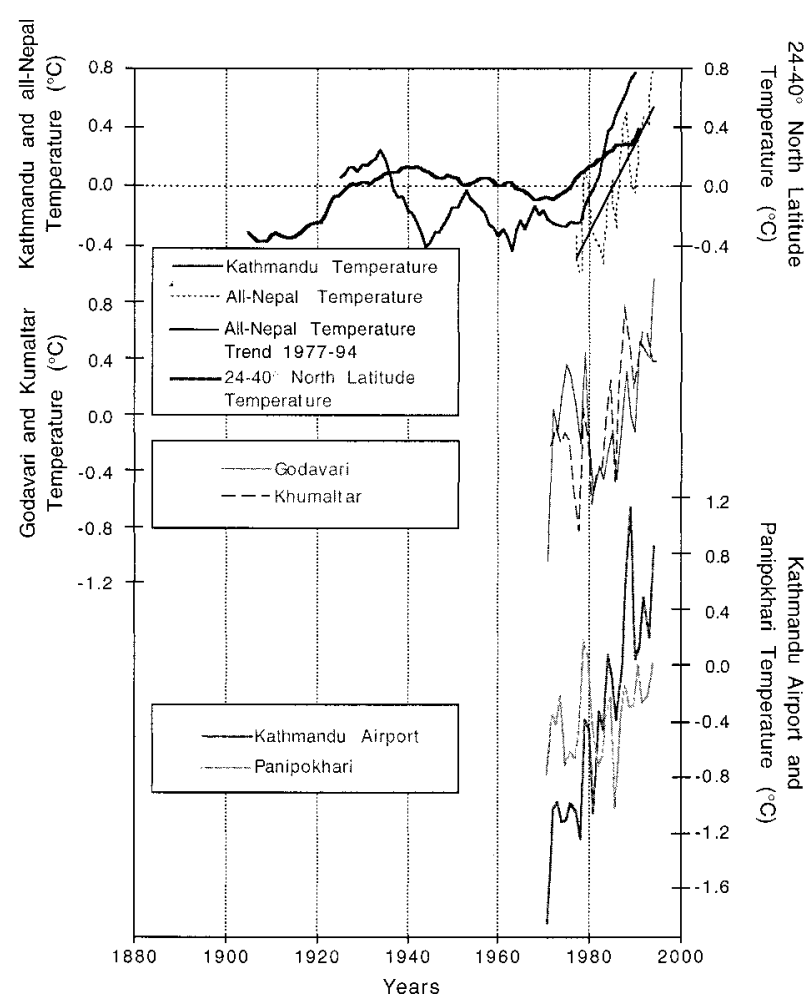

FIG. 5. Comparison between 10-yr running means of the Kathmandu record and $24^{\circ}-40^{\circ} \mathrm{N}$ temperature. For comparision, all-Nepal annual temperature series and 1977-94 trend are also presented here. Also four Kathmandu valley stations' records, used to construct the 1978-94 part in the Kathmandu temperature record, are included in this figure.

(Ekholm 1975; Hrabovsky and Miyan 1987; Karan 1987). Several studies have suggested a link between changes in air temperature and changes in land use and land cover, especially tropical deforestation (HendersonSellers and Gornitz 1984; Gash and Shuttleworth 1991). Sinha and Swaminathan (1991) have suggested possible climate change and its impact on agriculture as a result of deforestation in India. Meher-Homji (1991) suggested the possible impact on the hydrology of India related to deforestation. If the warming in Nepal is due to local land use and land cover changes, the highest warming should have been observed in the Terai and the Siwalik regions, which have experienced the greatest amount of land use/land cover changes over the past few decades. A recent study comparing aerial photographs taken in the late 1970s and satellite images taken in the early 1990s show deforestation in Terai at an average rate of $1.3 \% \mathrm{yr}^{-1}$ (FRSC 1994). A similar study has just been initiated for the Middle Mountain region. Preliminary results indicate that at the regional scale the forest cover has not changed significantly in the last 10-12 yr (R. Sharma 1997, personal communication). Since the Terai region actually shows the least amount of temperature increase over the past three decades, we suggest that the influence of land use and land cover change in the allNepal temperature is not significant; thus, these analyses are representative of actual climatic temperature trends in Nepal.

Growing numbers of studies suggest that increases in the atmospheric concentrations of greenhouse gases cause global warming (e.g., IPCC 1990). Near-synchronous warming as well as cooling trends in $24^{\circ}-40^{\circ} \mathrm{N}$ and Kathmandu between the period of 1920 to the mid1970s and similar synchronous warming in these two records as well as in the all-Nepal record after the mid1970s suggest that trends in all these records are due to some common forcing mechanism. Although it is not possible in the present study to suggest a possible forcing mechanism for the observed trends in Nepal, an increase in the concentrations of greenhouse gases could have played an important role.

\section{Conclusions}

Spatial distributions of maximum temperature trends in Nepal show high warming trends in most of the Himalayan region and the Middle Mountains, while low warming or even cooling trends are observed in most of the Terai and the Siwalik regions. Though the actual mechanisms are not well understood, monsoon circulation may play an important role in the distribution of seasonal temperatures as well as temperature trends. A study on trends of precipitation over Nepal currently in progress should provide additional information for understanding temperature trends found in the present study.

The longest temperature record from the country, the Kathmandu record, shows features similar to the $24^{\circ}-$ $40^{\circ} \mathrm{N}$ temperature record, namely, the cooling trends from 1935 to 1975 and warming trends thereafter, thereby suggesting connections with Northern Hemisphere temperature trends. Characteristics in the Kathmandu record are also very similar to those found in China and to some extent to those in northern India. The relatively higher magnitude of cooling and warming in the Kathmandu record is attributed to the physiographical characteristics of the Kathmandu valley and to its sensitivity to climatic changes. The warming after the mid-1970s may also be reflecting urbanization.

Several other locations in Nepal, which do not show overall growth rates comparable to Kathmandu, show warming trends of comparable or even higher rates than Kathmandu. The all-Nepal temperature record, with a spatial average of 49 station records, also shows similar warming after the mid-1970s. We suggest that the warming is not due to urban effects or local land use/cover changes, but is a widespread trend and is representative of regional-scale trends. It is the warming in the highelevation regions that contributes to the high warming rate in the all-Nepal record. We suggest that the Middle Mountain and High Himalayan regions are more sen- 
sitive to climate change due to their physiographic characteristics.

Acknowledgments. We thank Dr. B. Keim, Department of Geography, University of New Hampshire, and Dr. S. P. Adhikary, Himalayan Climate Center, Nepal. Thanks are extended to the Central Data Processing Unit, Department of Hydrology and Meteorology, Nepal, for providing some data in digital format. We also thank two anonymous reviewers, whose suggestions on the earlier version of the text helped a lot to improve it.

\section{REFERENCES}

Angell, J. K., and J. Korshover, 1978: Global temperature variation, surface-100 mb: An update into 1977. Mon. Wea. Rev., 106, $755-770$

Barnett, T. P., L. Dumenil, U. Schlese, and E. Roeckner, 1988: The effect of Eurasian snow cover on global climate. Science, 239, 504-507.

Barry, R. G., 1990: Changes in mountain climate and glacio-hydrological responses. Mt. Res. Dev., 10, 161-170.

Beniston, M., 1994: Introduction. Mountain Environments in Changing Climates, M. Beniston, Ed., Routledge, xxiv-xxxi.

CBS, 1995: Statistical Yearbook of Nepal 1995. Central Bureau of Statistics, Nepal, 446 pp.

Dey, B., and O. S. R. U. Bhanu Kumar, 1982: An apparent relationship between Eurasian spring snow cover and the advance period of the Indian summer monsoon. J. Appl. Meteor., 21, 1929-1932.

- and 1983: Himalayan winter snow cover area and summer monsoon rainfall over India. J. Geophys. Res., 88, 5471-5474.

DHM, 1998: Climatological records of Nepal 1991-1994. Department of Hydrology and Meteorology, HMG-Nepal, 232 pp. [Available from Department of Hydrology and Meteorology, P.O. Box 406 , Babar Mahal, Kathmandu, Nepal.]

Ekholm, E., 1975: The deterioration of mountain environment. Science, 189, 764-770.

EPC, 1993: Nepal environmental policy and action plan. Integrating environment and development. Environment Protection Council, His Majesty's Government of Nepal, 80 pp. [Available from Environment Protection Council, National Planning Commission, Singha Durbar, Kathmandu, Nepal.]

Follard, C. K., T. R. Karl, and K. Y. Vinnikov, 1990: Observed climate variations and change. Climate Change-The IPCC Scientific Assessment, J. T. Houghton, G. J. Jenkins, and J. J. Ephraums, Eds., Cambridge University Press, 195-238.

Fortner, B., 1992: The data handbook. A guide to understanding the organization and visualization of technical data. Spyglass Inc., Champaign, IL, 229 pp.

FRSC, 1994: Deforestation in the Terai districts 1978/79-1990/91. Publication 60, Forest Research and Survey Centre, Ministry of Forests and Soil Conservation, Kathmandu, Nepal, 9 pp. [Available from Forest Research and Survey Center, Ministry of Forests and Soil Conservation, P.O. Box 3339, Kathmandu, Nepal.]

Fujita, K., M. Nakawo, Y. Fujii, and P. Paudyal, 1997: Changes in glaciers in Hidden Valley, Mukut Himal, Nepal Himalayas, from 1974 to 1994. J. Glaciol., 43, 583-588.

Gash, J. H. C., and W. J. Shuttleworth, 1991: Tropical deforestation: Albedo and the surface-energy balance. Climate Change, 19, $123-133$.

Grabs, W. E., and A. P. Pokhrel, 1992: Establishment of measuring service for snow and glacier hydrology in Nepal-Conceptual and operational aspects. Proc. Int. Symp. on Snow and Glacier Hydrology, IAHS Publ. 218, Kathmandu, Nepal, WMO/GTZ/ UNESCO/ICIMOD/IAHS, 3-16.
Hansen, J., and S. Lebedeff, 1987: Global trends of measured surface air temperature. J. Geophys. Res., 92, 13 345-13 372.

— through 1987. Geophys. Res. Lett., 15, 323-326.

— R. Ruedy, M. Sato, and R. Reynolds, 1996: Global surface air temperature in 1995: Return to pre-Pinatubo level. Geophys. Res. Lett., 23, 1665-1668.

Henderson-Sellers, A., and V. Gornitz, 1984: Possible climatic impacts of land cover transformations, with particular emphasis on tropical deforestation. Climate Change, 6, 231-257.

Higuchi, K., H. Fushimi, T. Ohata, S. Takenaka, K. Yokoyama, H. Higuchi, A. Nagoshi, and T. Iozawa, 1980: Glacier inventory in the Dudh Kosi region, East Nepal. World glacier inventory. IAHS Publication No. 126, 95-103.

Hingane, L. S., K. R. Kumar, and B. V. R. Murty, 1985: Long term trends of surface air temperature in India. J. Climatol. 5, 521528.

Hrabovsky, J. P., and K. Miyan, 1987: Population growth and land use in Nepal. "The great turnabout." Mt. Res. Dev., 7, 264270.

IPCC, 1990: Climate Change-The IPCC Scientific Assessment. J. T. Houghton, G. J. Jenkins, and J. J. Ephraums, Eds., Cambridge University Press, 2-40.

Jones, P. D., S. C. B. Raper, R. S. Bradley, H. F. Diaz, P. M. Kelly, and T. M. L. Wigley, 1986a: Northern Hemisphere surface air temperature variations: 1851-1984. J. Climate Appl. Meteor., 25, 161-179.

$\longrightarrow, \ldots$, and T. M. L. Wigley, 1986b: Southern Hemisphere surface air temperature variations: 1851-1984. J. Climate Appl. Meteor., 25, 1213-1230.

—, T. M. L. Wigley, and P. B. Wright, 1986c: Global temperature variations between 1861 and 1984. Nature, 322, 430-434.

Kadota, T., and Y. Ageta, 1992: On the relation between climate and retreat of Glacier AX010 in the Nepal Himalaya from 1978 to 1989. Bull. Glacier Res., 10, 1-10.

- K. Seko, and Y. Ageta, 1993: Shrinkage of Glacier AX010 since 1978, Shorong Himal, East Nepal. Snow and Glacier Hydrology. IAHS Publication No. 218, 410 pp. [Available from Institute of Hydrology, Wallingford, Oxfordshire OX10 8BB, United Kingdom.]

Karan, P. P., 1987: Population characteristics of the Himalayan region. Mt. Res. Dev., 7, 271-274.

Khandekar, M. L., 1991: Eurasian snow cover, Indian monsoon and El Niño. Atmos.-Ocean, 29, 636-647.

Kothyari, U. C., and V. P. Shing, 1996: Rainfall and temperature trends in India. Hydrol. Processes, 10, 357-372.

Li, C., and M. Tang, 1986: Changes in air temperature in QinghaiXizang Plateau and its neighborhood in the recent 30 years. Plateau Meteor., 5, 332-341.

Mayewski, P. A., and P. A. Jeschke, 1979: Himalayan and TransHimalayan glacier fluctuations since AD 1812. Arct. Alp. Res., 11, 267-287.

Meehl, G. A., 1994: Influence of the land surface in the Asian summer monsoon: External conditions versus internal feedbacks. J. Climate, 7, 1033-1049.

Meher-Homji, V. M., 1991: Probable impact of deforestation on hydrological processes. Climate Change, 19, 163-173.

Miller, M. M., 1989: Comparative accumulation regimes of Himalayan and Alaskan neves and the issue of global warming. Environment and Society in the Manaslu-Ganesh Region of the Central Nepal Himalaya, R. A. Marston, Ed., Foundation for Glacier and Environment Research and University of Idaho, 8996.

— , and R. A. Marston, 1989: Glacial response to climate change epeirogeny in the Nepalese Himalaya. Environment and Society in the Manaslu-Ganesh Region of the Central Nepal Himalaya, R. A. Marston, Ed., Foundation for Glacier and Environment Research and University of Idaho, 65-88.

Mitchell, J. R. J., 1961: The temperatures of cities. Weatherwise, 14, 224-237. 
Seko, K., and S. Takahashi, 1991: Characteristics of winter precipitation and its effect on glaciers in the Nepal Himalaya. Bull. Glacier Res., 9, 9-16.

Shankar, K., and P. B. Shrestha, 1985: Climate. Nepal-Nature's Paradise, T. C. Majupuria, Ed., White Lotus, 39-44.

Sharma, B., 1986: Environmental aspects of urbanization in Kathmandu Valley. International Workshop in Planned Urbanization and Rural-Urban Linkages in the Hindu-Kush Himalayan Region, Kathmandu, Nepal, ICIMOD, 47 pp. [Available from ICIMOD, GPO Box 3226, Kathmandu, Nepal.]

Sinha, S. K., and M. S. Swaminathan, 1991: Deforestation, climate change and sustainable nutrition security: A case study of India. Climate Change, 19, 201-209.

Stone, P. B., Ed., 1992: The State of World's Mountains. Zed Books, $384 \mathrm{pp}$.
Sundborg, A., 1951: Local climatological studies of the temperature conditions in an urban area. Geographica, 22, 111-115.

Vuichard, D., and M. Zimmermann, 1987: The 1985 catastrophic drainage of a moraine-dammed lake, Khumbu Himal, Nepal: Cause and consequences. Mt. Res. Dev., 7, 91-110.

WECS, 1986: Erosion and sedimentation in Nepal. Rep. 4/3/010587/ 1/1, Water and Energy Commission Secretariat, Kathmandu, Nepal, 182 pp. [Available from Water and Energy Commission Secretariat (WECS), Singha Durbar, Kathmandu, Nepal.]

WMO, 1966: Climatic change. WMO Tech. Note 79, World Meteorological Organization, Geneva, Switzerland, $71 \mathrm{pp}$.

Yamada, T., T. Shiraiwa, H. Iida, T. Kadota, T. Watanabe, B. Rana, Y. Ageta, and H. Fushimi, 1992: Fluctuations of the glaciers from the 1970s to 1989 in the Khumbu, Shorong and Langtang regions, Nepal Himalayas. Bull. Glacier Res., 10, 11-19. 